\title{
Penggunaan TOGAF ADM 9.1 Pada Perancangan Enterprise Architecture Fungsi Layanan Beasiswa Universitas Kristen Maranatha
}

\author{
http://dx.doi.org/10.28932/jutisi.v5i1.888 \\ Rina Adrianti ${ }^{\# 1}$, Niko Ibrahim ${ }^{* 2}$

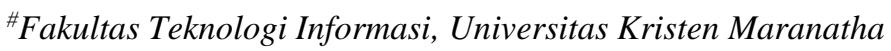 \\ Jl. Surya Sumantri No. 65 Bandung \\ ${ }^{1}$ rinaadriantil@gmail.com \\ ${ }^{2}$ niko.ibrahimeit.maranatha.edu
}

\begin{abstract}
In Indonesia, which poverty rates reaching $\mathbf{9 . 8 2 \%}$ in March 2018, education cost is a barrier for sections of societies with low household income. So that the availability of scholarships is a solution. Based on this, Maranatha Christian University provides tuition assistance in the form of scholarships for students with several categories, which are managed by Student Welfare Sector, under the supervision of the Directorate of Student Affairs. The problem in managing the scholarship is that there is no adequate system.

The goal is this research is to design a business strategy and information system strategy to achieve harmony based on present and future needs. TOGAF Framework, the enterprise architecture method is chosen to provide an effective and efficient solution from the business architecture phase, information system architecture phase, and technology architecture phase. The result of this research is in the form of TOGAF ADM artifact, as the blueprint architecture and IT development recommendations that are expected to be a guide in the development of scholarship services at Maranatha Christian University.
\end{abstract}

Keywords - Scholarship, Enterprise Architecture, TOGAF ADM, Analysis and Design

\section{Pendahuluan}

Berdasarkan data Badan Pusat Statistik, Indonesia memiliki tingkat kemiskinan mencapai 9,82\% pada Maret 2018 atau 25,95 juta orang [1]. Pendidikan tinggi, terutama S1 hingga S3 merupakan permasalahan yang cukup serius. Jatah pendidikan gratis ataupun pendidikan murah mungkin baru sebatas pendidikan dasar dan menengah saja [2]. Tingginya biaya pendidikan menjadi penghalang bagi sejumlah orang yang kemampuan ekonominya terbatas. Sehingga ketersediaan beasiswa merupakan solusi bagi mereka.

Beasiswa diartikan sebagai bentuk penghargaan yang diberikan untuk setiap individu agar dapat melanjutkan pendidikan ke jenjang yang lebih tinggi. Penghargaan itu dapat berupa akses tertentu pada satu institusi, atau penghargaan yang berupa bantuan keuangan [3].
Studi kasus yang dipilih yakni Universitas Kristen Maranatha (UKM). UKM merupakan salah satu perguruan tinggi swasta di Bandung yang menyediakan beasiswa untuk mahasiswa/i yang berprestasi dan yang memiliki keterbatasan ekonomi. Pemberian beasiswa pada UKM di kelola oleh Bagian Kesejahteraan Mahasiswa [4]. Bagian tersebut menangani pengelolaan bantuan beasiswa, baik beasiswa internal maupun eksternal yang dapat disesuaikan dengan kebutuhan yang diperlukan setiap mahasiswa/i yang membutuhkan bantuan biaya Pendidikan [5].

Adapun kendala yang ditemui yaitu: (i)Prosedur layanan beasiswa untuk mahasiswa/i aktif di Universitas Kristen Maranatha dilakukan secara manual dan data mahasiswa/i yang direkomendasikan Unit Kerja direkam dalam satu rekap digital (file excel), sehingga lebih rentan kesalahan. (ii)Tidak ada integrasi Bagian Kesejahteraan Mahasiswa sebagai pengelolah beasiswa dengan bidang lain yang terkait dalam proses layanan beasiswa kepada mahasiswa/i terpilih.

Keselarasan penerapan sistem informasi dengan kebutuhan organisasi hanya mampu dijawab dengan memperhatikan faktor integrasi didalam pengembangannya. Untuk menurunkan kesenjangan tersebut, maka diperlukan sebuah paradigma dalam merencanakan, merancang, dan mengelola sistem informasi yang disebut dengan Enterprise Architecture (EA). Berdasarkan permasalah diatas maka digunakan paradigma TOGAF ADM dalam perancangan Enterprise Architecture khususnya pada Business Architecture Phase, Information System Architecture Phase, Technology Architecture Phase sebagai solusi dalam mengembangkan sistem informasi yang terintegrasi untuk mendukung kebutuhan organisasi [6].

Adapun tujuan penelitian ini adalah: (1) Merancang enterprise architecture menggunakan TOGAF ADM pada fungsi layanan beasiswa Universitas Kristen Maranatha.

(2) Membuat kerangka dasar (blueprint) enterprise architecture sebagai landasan untuk pengembangan sistem pengelolaan beasiswa pada Universitas Kristen Maranatha. 


\section{TINJAUAN PUSTAKA}

A. Enterprise Architecture

Pengertian Enterprise Architecture menurut beberapa ahli:

1. Menurut Daniel Minoli: Enterprise Architecture adalah sebuah manajemen dan penerapan teknologi yang disediakan untuk mengembangkan kinerja bisnis dengan mengevaluasi dari pandangan strategi, praktik bisnis, alur, informasi dan sumber teknologi [7].

2. Menurut Scott A. Bernard: Enterprise Architecture adalah praktik profesi dan manajemen yang muncul yang ditujukan untuk meningkatkan kinerja perusahaan dengan memungkinkan mereka untuk melihat diri perusahaan itu sendiri secara holistic dan melihat terintegrasi arah strategis, praktik bisnis, arus informasi dan sumber daya teknologi [8].

3. Menurut The Open Group Architectural Framework (TOGAF): Enterprise Architecture adalah sekumpulan strategis dan disiplin arsitektural yang meliputi informasi, sistem bisnis, dan arsitektur teknis [9].

Terdapat empat domain arsitektur yang diterima secara umum sebagai bagian dari keseluruhan arsitektur enterprise. Keempat domain tersebut telah telah didukung oleh TOGAF [9], yaitu:

1. Arsitektur bisnis mendefinisikan strategi bisnis, peraturan, organisasi, dan proses bisnis utama dari sebuah organisasi.

2. Arsitektur data mendeskripsikan struktur fisik dan logika dari aset data pada organisasi.

3. Arsitektur aplikasi menyediakan cetak biru sistem aplikasi untuk dideploy, interaksinya dan hubungannya dengan proses bisnis utama dari organisasi.

4. Arsitektur teknologi mendeskripsikan komponen perangkat lunak dan perangkat keras yang dibutuhkan untuk mendukung arsitektur bisnis, data dan aplikasi.

\section{B. TOGAF Architectural Development Method (ADM)}

TOGAF Architectural Development Method (ADM) menyediakan suatu siklus proses spesifik yang terdiri dari delapan fase utama untuk pengembangan dan pemeliharaan arsitektur teknologi informasi suatu organisasi, yang terdiri dari business architecture, data architecture, application architecture, dan technical architecture [9]. ADM juga bisa digunakan sebagai panduan atau alat untuk merencanakan, merancang, mengembangkan dan menerapkan arsitektur sistem informasi untuk organisasi [10]. Pada setiap tahapan dalam ADM akan dilakukan pembahasan tentang masukan (input), keluaran (output), dan langkah-langkah yang menjelaskan sejumlah produk kerja arsitektur seperti proses dan aplikasi. Tahapan-tahapan dalam TOGAF ADM dapat dilihat pada Gambar 1.

\section{Pengelolaan Beasiswa di Universitas Kristen Maranatha}

Universitas kristen Maranatha (UKM) adalah universitas swasta yang terletak di Jl. Prof Drg. Surya Sumantri No. 56 Bandung yang berdiri pada tanggal 11 September 1965.

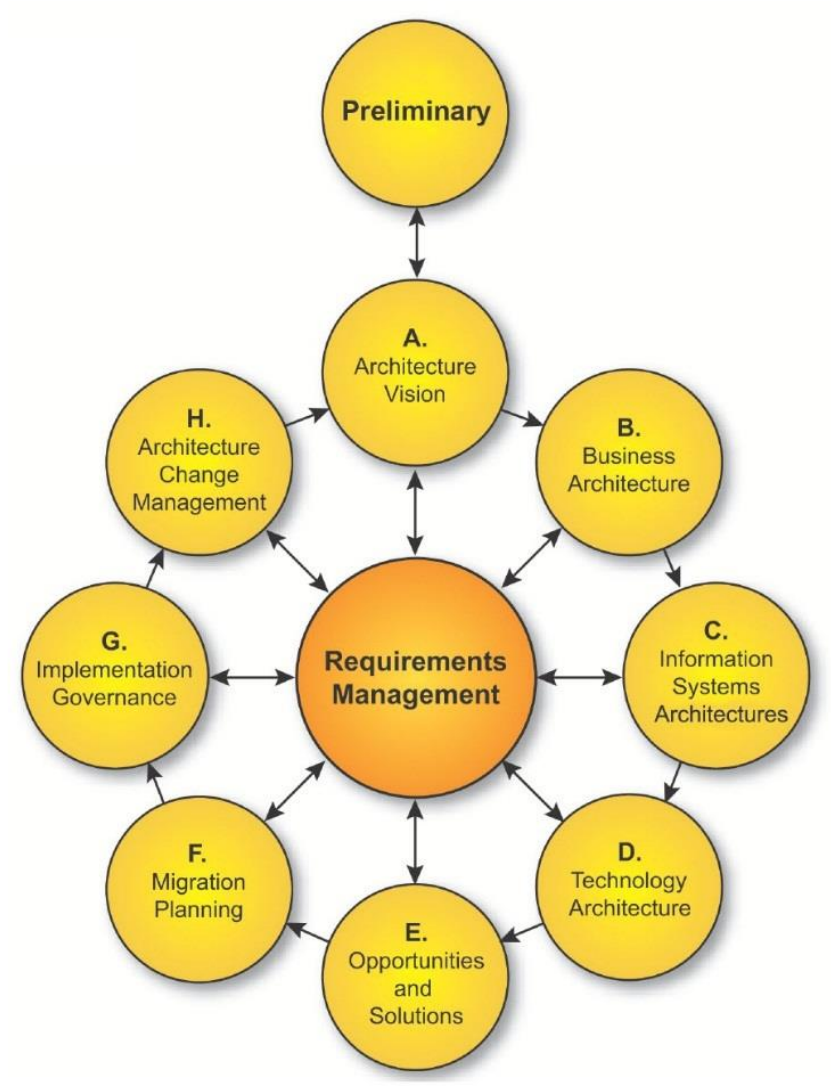

Gambar 1: TOGAF Architectural Development Method (ADM) [9]

\section{STUDI KASUS}

Pengelolaan beasiswa di UKM dikelola oleh Direktorat Kemahasiswaan. Direktorat Kemahasiswaan adalah bagian dari pendukung program layanan kepada mahasiswa khususnya dalam mengembangkan kegiatan kemahasiswaan bidang penalaran, minat dan kegemaran, pengembangan kepemimpinan dan karakter, kesejahteraan dan konseling mahasiswa serta pengabdian kepada masyarakat oleh mahasiswa.

Pemberian beasiswa pada Universitas Kristen Maranatha dikelompokkan ke dalam 3 kategori yakni beasiswa internal, beasiswa eksternal, dan beasiswa khusus [5].

1. Beasiswa Internal

Beasiswa internal yakni beasiswa yang diberikan dengan sumber dana dari Universitas Kristen Maranatha, bagi mahasiswa-mahasiswi Universitas Kristen Maranatha yang aktif, berprestasi atau dari latar belakang keluarga berekonomi marginal sesuai dengan syarat dan ketentuan yang berlaku.

Adapun pengelompokkan beasiswa internal adalah sebagai berikut [5]:

1) Beasiswa Universitas Kristen Maranatha 
a. Beasiswa Pegawai YPTKM

Merupakan beasiswa dalam bentuk pengurangan biaya pendidikan yang diberikan kepada anak Pegawai YPTKM yang akan dan telah terdaftar secara sah sebagai peserta didik di Universitas Kristen Maranatha.

b. Beasiswa Prestasi

Merupakan reward kepada mahasiswa yang dinilai berprestasi. Reward diberikan berupa pengurangan biaya yang menjadi kewajiban keuangan. Besaran reward diberikan sesuai dengan kategori prestasi.

2) Beasiswa YPTKM

a. Beasiswa Badan Pendukung

Merupakan beasiswa yang ditetapkan oleh pengurus YPTKM berdasarkan rekomendasi dari Pengurus Yayasan Badan Pendidikan Kristen (BPK PENABUR) melalui Unit Beasiswa Badan Pendidikan Kristen PENABUR (UBS BPK PENABUR) dan Pengurus Yayasan Badan Pendidikan Kristen Gereja Kristen Pasundang Bandung (YBPK GKPB)

b. Beasiswa Keluarga Badan Pendukung

Merupakan beasiswa dalam bentuk pengurangan biaya pendidikan yang diberikan kepada anak kandung atau anak angkat yang dapat dibuktikan secara sah.

c. Beasiswa untuk Anak Pendeta Gereja

d. Merupakan beasiswa dalam bentuk pengurangan biaya pendidikan bagi anak kandung dari Pendeta Gereja di luar Gereja Kristen Pasundan dan atau Gereja Kristen Indonesia

2. Beasiswa External

Beasiswa yang dikelola oleh Universitas Kristen Maranatha bagi mahasiswa-mahasiswi Universitas Kristen Maranatha dengan adanya kerjasama dengan pihak pemberi beasiswa bersumber eksternal. Pembukaan beasiswa eksternal, diumumkan secara berkala, sesuai dengan periode waktu yang ditentukan oleh pemberi beasiswa.

3. Beasiswa Khusus

Program beasiswa khusus Universitas Kristen Maranatha bekerja sama dengan MetroTVNews.com, yang memberikan kesempatan beasiswa studi S-1 selama 4 tahun dan $100 \%$ bebas uang pangkal bagi para pemenang.

\section{HASIL PENELITIAN}

Pada bab ini membahas perancangan kerangka arsitektur enterprise menggunakan TOGAF ADM yang di dalamnya terdapat beberapa fase atau tahapan yang dilakukan untuk merancang enterprise architecture, fase-fase tersebut dimulai dari Phase B Business Architecture, Phase $C$
Information System Architecture, dan Phase D Technology Architecture.

\section{A. Phase B: Business Architecture Phase}

Pada fase ini akan dijabarkan dan digambarkan model bisnis yang berjalan saat ini, keadaaan struktur bidangbidang yang menangani pengelolaan beasiswa internal maupun eksternal di Universitas Kristen Maranatha, serta usulan yang dapat diimplementasikan untuk proses bisnis di masa yang akan datang. Scope proses bisnis yang dijalankan dan pemodelan mengenai proses bisnis tersebut dengan menggunakan flowchart.

1. Arsitektur Bisnis

Arsitektur bisnis ini menjelaskan mengenai keadaan arsitektur pada pengelolaan beasiswa pada Universitas Kristen Maranatha saat ini, seperti bagaimana prosedur layanan pengelolaan beasiswa, scope proses bisnis yang dijalankan, baseline arsitecture, pemodelan mengenai proses bisnis usulan pada target architecturedan gap analysis antara baseline architecture dan target architecture.

1) Identifikasi scope bisnis yang ditangani Beasiswa Internal terdiri dari:

a) Beasiswa Anak Pegawai YPTKM

b) Beasiswa Prestasi Akademik

c) Beasiswa Prestasi Non Akademik

d) Beasiswa Prestasi Ekonomi Lemah

e) Beasiswa Prestasi Mahasiswa Baru

Sedangkan, beasiswa eksternal terdiri dari dana yang berasal dari luar Universitas Kristen Maranatha. Berikut ini beberapa beasiswa eksternal:

a) Beasiswa $\mathrm{BNI}$

b) Beasiswa BCA

c) Beasiswa Djarum Beasiswa Plus

d) Beasiswa Bidik Misi

e) Beasiswa Indomaret

2) Deskripsi Aktor

Proses bisnis tidak akan berjalan apabila tidak terdapat aktor yang menjalankannya. Berdasarkan hasil wawancara maka didapatkan beberapa aktor yang terlibat dalam proses bisnis layanan beasiswa pada Univetsitas Kristen Maranartha yang dijelaskan pada tabel I untuk beasiswa internal dan tabel II untuk beasiswa eksternal:

TABEL I

DESKRIPSI AKTOR UNTUK BEASISWA INTERNAL

\begin{tabular}{|c|c|c|}
\hline No & Nama Aktor & Deskripsi \\
\hline 1 & Mahasiswa/i & $\begin{array}{l}\text { Orang yang mengajukan } \\
\text { beasiswa } \\
\text { Orang yang mengisi formulir dan } \\
\text { kelengkapan berkas persyaratan } \\
\text { utama dan khusus }\end{array}$ \\
\hline 2 & $\begin{array}{l}\text { Direktur } \\
\text { Kemahasiswa } \\
\text { an }\end{array}$ & $\begin{aligned} & \text { Orang yang menyetujui } \\
& \text { pembukaan beasiswa } \\
> & \text { Orang yang menandatangani }\end{aligned}$ \\
\hline
\end{tabular}




\begin{tabular}{|c|c|c|}
\hline No & Nama Aktor & Deskripsi \\
\hline & & $\begin{array}{l}\text { surat pernyataan tidak sedang } \\
\text { menerima beasiswa } \\
\text { Orang yang mengetahui } \\
\text { penerima beasiswa dan } \\
\text { mahasiswa yang tidak menerima } \\
\text { beasiswa }\end{array}$ \\
\hline 3 & $\begin{array}{l}\text { Kepala } \\
\text { Bidang } \\
\text { Kesejahteraan } \\
\text { Mahasiswa }\end{array}$ & $\begin{aligned} & \text { Orang yang mengetahui } \\
& \text { pembukaan beasiswa } \\
& \text { Orang yang menyiapkan formulir } \\
& \text { beasiswa } \\
& \text { Orang yang menerima berkas } \\
& \text { pengajuan beasiswa internal } \\
& \text { khusus untuk ajuan beasiswa } \\
& \text { prestasi akademik mahasiswa } \\
& \text { baru } \\
&>\text { Orang yang melakukan } \\
& \text { penetapan persentase untuk } \\
& \text { mahasiswa yang menerima } \\
& \text { beasiswa } \\
&>\text { Orang yang melakukan proses } \\
& \text { menerbitkan surat persetujuan } \\
& \text { beasiswa melalui pengecekan } \\
& \text { plafon nominal ajuan beasiswa } \\
& \text { yang diberikan Wakil Rektor II } \\
& \text { untuk setiap program studi } \\
& \text { Orang yang menerbitkan Surat } \\
& \text { Persetujuan Beasiswa } \\
&>\text { Orang yang menerbitkan Surat } \\
& \text { Penolakan Beasiswa } \\
& \text { Orang yang mendistribusikan } \\
& \text { Surat Persetujuan Beasiswa dan } \\
& \text { besaran beasiswa kepada } \\
& \text { Direktorat Keuangan untuk } \\
& \text { proses pemotongan tagihan } \\
& \text { kewajiban keuangan } \\
& \text { Orang yang menandatangani } \\
& \text { surat pernyataan tidak sedang } \\
& \text { menerima beasiswa } \\
& \text { Orang yang memverifikasi } \\
& \text { berkas ajuan mahasiswa } \\
&\end{aligned}$ \\
\hline 4 & $\begin{array}{l}\text { Staf Bidang } \\
\text { Kesejahteraan } \\
\text { Mahasiswa }\end{array}$ & $\begin{aligned} & \text { Orang yang mengumumkan } \\
& \text { pembukaan beasiswa internal } \\
& \text { melalui surat dan media publikasi } \\
& \text { resmi kepada seluruh fakultas } \\
& \text { dilingkungan universitas } \\
&>\text { Orang yeng menyiapkan formulir } \\
& \text { beasiswa } \\
&>\text { Orang yang melakukan } \\
& \text { pengarsipan rekap dan secara } \\
& \text { berkala melakukan monitoring } \\
& \text { dan evaluasi berupa survey } \\
& \text { kepada penerima beasiswa di } \\
& \text { semester berjalan. } \\
&>\text { Orang yang menerima berkas } \\
& \text { pengajuan beasiswa internal } \\
& \text { khusus untuk ajuan beasiswa } \\
& \text { prestasi akademik mahasiswa } \\
& \text { baru }\end{aligned}$ \\
\hline
\end{tabular}

\begin{tabular}{|c|c|c|}
\hline No & Nama Aktor & Deskripsi \\
\hline & & $\begin{array}{l}\text { penerima beasiswa } \\
\text { Orang yang mendistribusikan } \\
\text { Surat Persetujuan Beasiswa } \\
\text { kepada masing-masing Unit } \\
\text { Kerja yang terlibat sesuai dengan } \\
\text { jenis beasiswa internal yang } \\
\text { diajukan } \\
>\text { Orang yang mendistribusikan } \\
\text { Surat Persetujuan Beasiswa } \\
\text { kepada masing-masing Unit } \\
\text { Kerja yang terlibat sesuai dengan } \\
\text { jenis beasiswa internal yang } \\
\text { diajukan }\end{array}$ \\
\hline 5 & Fakultas & $\begin{aligned} & \text { Orang yang mengumumkan } \\
& \text { informasi pembukaan beasiswa } \\
& \text { internal di media yang dimiliki } \\
& \text { oleh fakultas } \\
& \text { Orang yang menerima berkas } \\
& \text { pengajuan beasiswa internal dari } \\
& \text { mahasiswa sesuai dengan } \\
& \text { kategori beasiswa yang diajukan } \\
& \text { mahasiswa } \\
& \text { Orang yang memeriksa } \\
& \text { kelengkapan berkas pengajuan } \\
& \text { beasiswa berdasarkan kelayakan } \\
& \text { pengajuan minimum syarat } \\
& \text { utama dan khusus } \\
&>\text { Orang yang merekap daftar } \\
& \text { beasiswa dan meneruskan berkas } \\
& \text { asli kepada Direktorat } \\
& \text { Kemahasiswaan } \\
& \text { Orang yang menerima surat } \\
& \text { persetujuan beasiswa }\end{aligned}$ \\
\hline 6 & $\begin{array}{l}\text { Struktural } \\
\text { Fakultas } \\
\text { (Dekan dan } \\
\text { Wakil Dekan) }\end{array}$ & $\begin{array}{l}\text { Orang yang melakukan } \\
\text { wawancara kepada mahasiswa } \\
\text { yang mengajukan beasiswa } \\
\text { Orang yang mengecek plafon } \\
\text { sesuai dengan Rencana Program } \\
\text { Kerja dan Anggaran yang } \\
\text { disetujui } \\
\text { Orang yang memberikan atau } \\
\text { monolak rekomendasi untuk } \\
\text { mahasiswa yang menerima } \\
\text { beasiswa }\end{array}$ \\
\hline 7 & $\begin{array}{l}\text { Staf } \\
\text { Direktorat } \\
\text { Sumber Daya } \\
\text { dan } \\
\text { Pengembanga } \\
\text { n Insani }\end{array}$ & $\begin{array}{l}\text { Orang yang menerima berkas } \\
\text { dari pegawai YPTKM yang } \\
\text { mengajukan beasiswa } \\
\text { Orang yang melakukan } \\
\text { pengecekan masa kerja orang tua } \\
\text { sehingga bisa di tetapkan } \\
\text { presentase beasiswa yang di } \\
\text { terima } \\
\text { Menerima surat persetujuan } \\
\text { beasiwa untuk anak pegawai, } \\
\text { anak pensiunan, dan anak } \\
\text { pegawai tidak tetap YPTKM }\end{array}$ \\
\hline 8 & $\begin{array}{l}\text { Direktur } \\
\text { Sumber Daya } \\
\text { dan } \\
\text { Pengembanga } \\
\text { n Insani }\end{array}$ & $\begin{array}{l}\text { Orang yang menerima berkas } \\
\text { ajuan beasiswa anak pegawai } \\
\text { untuk di tanda tangan untuk } \\
\text { direkomendasikan menerima } \\
\text { beasiswa }\end{array}$ \\
\hline
\end{tabular}




\begin{tabular}{|c|l|l|}
\hline No & Nama Aktor & \multicolumn{1}{c|}{ Deskripsi } \\
\hline 9 & $\begin{array}{l}\text { Wakil Rektor } \\
\text { III (Direktorat } \\
\text { Kemahasiswa } \\
\text { an }\end{array}$ & $>\begin{array}{l}>\text { Orang yang memberikan } \\
\text { persetujuan penerbitan Surat } \\
\text { Penerimaan dan Penolakan } \\
\text { Beasiswa }\end{array}$ \\
\hline 10 & Rektor & $>\begin{array}{l}>\text { Orang yang memberikan } \\
\text { persetujuan penerbitan Surat } \\
\text { Penerimaan Beasiswa } \\
>\text { Orang yang menerima rekap } \\
\text { penerima beasiswa }\end{array}$ \\
\hline 11 & Wakil Rektor & $>\begin{array}{l}\text { Orang yang mengetahui } \\
\text { penerima beasiswa }\end{array}$ \\
\hline 12 & $\begin{array}{l}>\text { Orang yang mempertimbangkan } \\
\text { adanya penambahan plafon } \\
\text { beasiswa }\end{array}$ \\
& Keuangan & $\begin{array}{l}>\text { Orang yang melakukan } \\
\text { pemotongan tagihan kewajiban } \\
\text { keuangan mahasiswa sesuai } \\
\text { dengan besaran jumlah beasiswa } \\
\text { yang diperoleh setiap mahasiswa. }\end{array}$ \\
& $>\begin{array}{l}\text { Orang yang mengetahui } \\
\text { penerima beasiswa }\end{array}$ \\
\hline
\end{tabular}

Berikut dibawah ini tabel II, yang berisi daftar aktor yang terlibat dalam proses layanan beasiswa eksternal sebagai berikut:

TABEL II

DESKRIPSI AKTOR UNTUK BEASISWA EKSTERNAL

\begin{tabular}{|c|c|c|}
\hline No & Nama Aktor & Deskripsi \\
\hline 1 & $\begin{array}{l}\text { Direktur } \\
\text { Kemahasiswaan }\end{array}$ & $\begin{array}{l}\text { Orang yang mengetahui } \\
\text { pembukaan beasiswa eksternal }\end{array}$ \\
\hline 2 & $\begin{array}{l}\text { Kepala Bidang } \\
\text { Kesejahteraan } \\
\text { Mahasiswa }\end{array}$ & $\begin{array}{l}\text { Orang yang mengetahui } \\
\text { pembukaan beasiswa eksternal } \\
\text { Orang yang melakukan } \\
\text { pengecekan berkas mahasiswa } \\
\text { dan menandatangani surat } \\
\text { pernyataan tidak sedang } \\
\text { menerima beasiswa lain } \\
\text { Orang yang mengetahui segala } \\
\text { prosedur layanan beasiswa }\end{array}$ \\
\hline 3 & $\begin{array}{l}\text { Staff Bidang } \\
\text { Kesejahteraan } \\
\text { Mahasiswa }\end{array}$ & 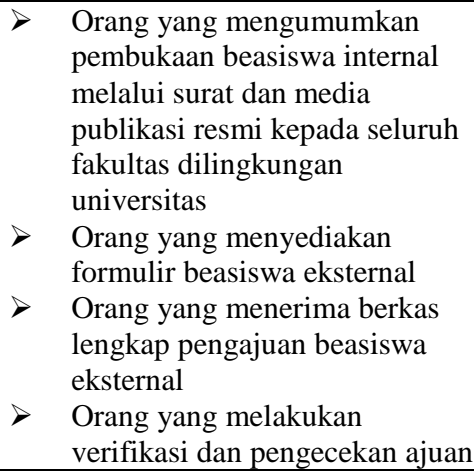 \\
\hline
\end{tabular}

\begin{tabular}{|c|c|c|}
\hline No & Nama Aktor & Deskripsi \\
\hline & & $\begin{array}{ll}\text { berkas } \\
\text { Orang yang melakukan rekap } \\
\text { pengajuan beasiswa } \\
\text { Orang yang mengirim berkas } \\
\text { ajuan mahasiswa kepada } \\
\text { pemberi beasiswa eksternal } \\
\text { Orang yang menerima surat } \\
\text { pemberitahuan penerima } \\
\text { beasiswa dari pemberi beasiswa } \\
\text { eksternal } \\
\text { Orang yang mengumumkan } \\
\text { penerima beasiswa eksternal } \\
\text { Orang yang mendistribusikan } \\
\text { informasi penerima beasiswa } \\
\text { dan besaran beasiswa eksternal } \\
\text { kepada Direktorat Keuangan } \\
\text { untuk proses pemotongan } \\
\text { tagihan atau pengembalian } \\
\text { kewajiban keuangan } \\
\text { Orang yang membuat laporan } \\
\text { rekap penerima beasiswa } \\
\text { eksternal kepada Rektor, } \\
\text { melalui surat yang diterbitkan } \\
\text { oleh Wakil Rektor III } \\
\text { Orang yang melakukan } \\
\text { pengarsipan secara berkala dan } \\
\text { melakukan monitoring dan } \\
\text { evaluasi berupa survey kepada } \\
\text { pemberi maupun penerima } \\
\text { beasiswa di akhir semester. }\end{array}$ \\
\hline 4 & Mahasiswa & 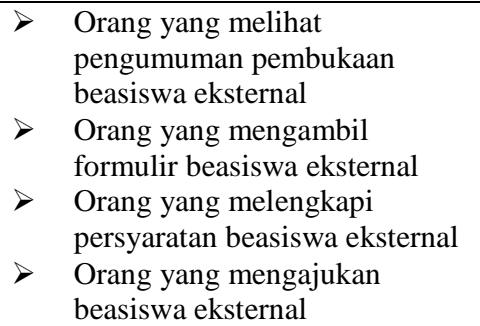 \\
\hline 5 & Fakultas & $\begin{array}{l}\text { Orang yang mengumumkan } \\
\text { pembukaan beasiswa eksternal } \\
\text { pada media fakultas }\end{array}$ \\
\hline 6 & $\begin{array}{l}\text { Struktural } \\
\text { Fakultas }\end{array}$ & $\begin{array}{l}\text { Orang yang memberikan } \\
\text { rekomendasi kepada mahasiswa } \\
\text { yang mengajukan beasiswa } \\
\text { eksternal }\end{array}$ \\
\hline 7 & $\begin{array}{l}\text { Pemberi } \\
\text { Beasiswa }\end{array}$ & $\begin{array}{l}\text { Orang yang menerima berkas } \\
\text { ajuan beasiswa eksternal } \\
\text { Orang yang melalukan seleksi } \\
\text { penerimaan beasiswa eksternal } \\
>\quad \begin{array}{l}\text { Orang yang membuat surat } \\
\text { pemberitahuan penerima } \\
\text { beasiswa }\end{array} \\
\end{array}$ \\
\hline 8 & $\begin{array}{l}\text { Direktorat } \\
\text { Keuangan }\end{array}$ & $\begin{array}{l}\text { Orang yang menerima daftar } \\
\text { penerima beasiswa eksternal } \\
\text { Orang yang melakukan } \\
\text { pemotongan tagihan sesuai } \\
\text { besaran beasiswa eksternal yang } \\
\text { diperoleh atau pengembalian } \\
\text { kewajiban keuangan (khusus } \\
\text { untuk beasiswa yang dananya }\end{array}$ \\
\hline
\end{tabular}




\begin{tabular}{|c|l|ll|}
\hline No & Nama Aktor & \multicolumn{1}{c|}{ Deskripsi } \\
\hline & & & $\begin{array}{l}\text { masuk ke Universitas Kristen } \\
\text { Maranatha) }\end{array}$ \\
\hline 9 & Wakil Rektor III & $>\begin{array}{l}\text { Orang yang membuat surat } \\
\text { laporan rekap penerima } \\
\text { beasiswa eksternal } \\
\text { Orang yang mengetahui } \\
\text { penerima beasiswa eksternal }\end{array}$ \\
\hline 10 & Rektor & $>\begin{array}{l}\text { Orang yang mengetahui } \\
\text { penerima beasiswa eksternal }\end{array}$ \\
\hline
\end{tabular}

3) Gap Analysis Arsitektur Bisnis

Berikut ini adalah tabel III, yang menampilkan gap analysis arsitektur bisnis dari sistem beasiswa internal:

\section{TABEL III}

GAP ANALYSIS ARSITEKTUR BISNIS BEASISWA INTERNAL

\begin{tabular}{|c|c|c|}
\hline No & Baseline Architecture & Target Architecture \\
\hline 1 & $\begin{array}{l}\text { Proses pengumuman } \\
\text { beasiswa internal dan } \\
\text { eksternal dilakukan secara } \\
\text { manual dengan } \\
\text { menyebarkan dokumen } \\
\text { pengumuman pembukaan } \\
\text { beasiswa kepada setiap } \\
\text { fakultas }\end{array}$ & $\begin{array}{l}\text { Proses pengumuman } \\
\text { pembukaan beasiswa } \\
\text { internal maupun eksternal } \\
\text { diharapkan dapat } \\
\text { menggunakan sistem } \\
\text { sehingga pengumuman bisa } \\
\text { langsung diakses oleh setiap } \\
\text { mahasiswa lewat } \\
\text { sistemlayanan beasiswa }\end{array}$ \\
\hline 2 & $\begin{array}{l}\text { Proses pengajuan beasiswa } \\
\text { internal dan eksternal } \\
\text { menggunakan form yang } \\
\text { diperoleh dari Bidang } \\
\text { Kesejahteraan Mahasiswa } \\
\text { diisi secara manual }\end{array}$ & $\begin{array}{l}\text { Proses pengajuan beasiswa } \\
\text { internal dan eksternal } \\
\text { diharapkan dapat } \\
\text { menggunakan sistem } \\
\text { sehingga mahasiswa bisa } \\
\text { melakukan pengajuan } \\
\text { beasiswa dilakukan dengan } \\
\text { mengisi form yang ada pada } \\
\text { sistem beasiswa }\end{array}$ \\
\hline 3 & $\begin{array}{l}\text { Proses verifikasi kelayakan } \\
\text { berkas dilakukan secara } \\
\text { manual }\end{array}$ & $\begin{array}{l}\text { Proses verifikasi kelayakan } \\
\text { berkas diharapkan dapat } \\
\text { menggunakan sistem } \\
\text { sehingga mahasiswa yang } \\
\text { sesuai persyaratan yang bisa } \\
\text { mengajukan beasiswa }\end{array}$ \\
\hline 4 & $\begin{array}{l}\text { Proses delivery berkas } \\
\text { untuk mahasiswa yang } \\
\text { direkomendasikan masih } \\
\text { manual dengan cara unit } \\
\text { kerja memberikan secara } \\
\text { langsung kepada Bidang } \\
\text { Kesejahteraan Mahasiswa } \\
\text { berkas ajuan mahasiswa } \\
\text { untuk di olah kembali } \\
\end{array}$ & $\begin{array}{l}\text { Proses pengiriman nama } \\
\text { serta berkas pengajuan } \\
\text { mahasiswa yang } \\
\text { direkomendasikan } \\
\text { diharapkan } \\
\text { dapatmenggunakan sistem } \\
\text { sehingga tidak perlu lagi } \\
\text { untuk mengantarkan berkas } \\
\text { mahasiswa lewat ekspedisi }\end{array}$ \\
\hline 5 & $\begin{array}{l}\text { Proses penerimaan } \\
\text { mahasiswa yang } \\
\text { direkomendasikan } \\
\text { diinputkan kembali oleh } \\
\text { Bidang Kesejahteraan } \\
\text { Mahasiswa dalam file } \\
\text { digital (Excel) }\end{array}$ & $\begin{array}{l}\text { Proses penerimaan } \\
\text { mahasiswa yang } \\
\text { direkomendasikan } \\
\text { diharapkan dapat } \\
\text { menggunakan sistem untuk } \\
\text { transfer data mahasiswa } \\
\text { yang di rekomendasikan } \\
\text { sehingga tidak perlu } \\
\text { penginputan ulang dan } \\
\text { verifikasi kelayakan berkas }\end{array}$ \\
\hline
\end{tabular}

\begin{tabular}{|l|l|l|}
\hline No & \multicolumn{1}{|c|}{ Baseline Architecture } & \multicolumn{1}{c|}{ Target Architecture } \\
\hline 6 & $\begin{array}{l}\text { Proses perekapan } \\
\text { mahasiswa yang menerima } \\
\text { beasiswa masih dilakukan } \\
\text { dalam bentuk file excel }\end{array}$ & $\begin{array}{l}\text { Proses perekapan } \\
\text { mahasiswa yang menerima } \\
\text { beasiswa diharapkan dapat } \\
\text { menggunakan sistem } \\
\text { sehingga tidak perlu lagi } \\
\text { melakukan rekap penerima } \\
\text { beasiswa karena ketika } \\
\text { menerbitkan surat penerima } \\
\text { beasiswa secara otomatis } \\
\text { sistem akan melakukan } \\
\text { pemisahan laporan penerima } \\
\text { beasiswa }\end{array}$ \\
\hline 7 & $\begin{array}{l}\text { Unit kerja yang melakukan } \\
\text { verifikasi atau } \\
\text { rekomendasi kepada } \\
\text { mahasiswa tidak dipisah } \\
\text { aktor atau bidang mana } \\
\text { yang menangani kategori } \\
\text { beasiswa yang diajukan } \\
\text { mahasiswa sehingga } \\
\text { proses bisnis tidak } \\
\text { tergambarkan secara detail }\end{array}$ & $\begin{array}{l}\text { Proses bisnis untuk unit } \\
\text { kerja dipisah dalam } \\
\text { beberapa aktor sesuai } \\
\text { dengan kategori yang } \\
\text { diajukan mahasiswa, } \\
\text { sehingga proses bisnis bisa } \\
\text { dijabarkan secara detail }\end{array}$ \\
\hline
\end{tabular}

Berikut ini adalah tabel IV, yang menampilkan gap analysis arsitektur bisnis dari sistem beasiswa eksternal:

TABEL IV

GAP ANALYSIS ARSITEKTUR BISNIS BEASISWA EKSTERNAL

\begin{tabular}{|c|c|c|}
\hline No & Baseline Architecture & Target Architecture \\
\hline 1 & $\begin{array}{l}\text { Proses pengumuman } \\
\text { layanan beasiswa } \\
\text { eksternal masih bersifat } \\
\text { manual }\end{array}$ & $\begin{array}{l}\text { Proses layanan beasiswa } \\
\text { eksternal diharapkan } \\
\text { memiliki sistem informasi } \\
\text { tentang beasiswa } \\
\text { Universitas Krsiten } \\
\text { Maranatha sehingga lebih } \\
\text { memudahkan mahasiswa } \\
\text { untuk mengecek informasi } \\
\text { pembukaan beasiswa }\end{array}$ \\
\hline 2 & $\begin{array}{l}\text { Proses pengambilan form } \\
\text { beasiswa internal masih } \\
\text { manual dengan datang } \\
\text { langsung ke kantor } \\
\text { Kemahasiswaan }\end{array}$ & $\begin{array}{l}\text { Diharapkan terdapatnya } \\
\text { sistem yang menyediakan } \\
\text { layanan unduh form } \\
\text { persyaratan pendaftaran } \\
\text { beasiswa eksternal dan } \\
\text { dapat mengisi data } \\
\text { mahasiswa menggunakan } \\
\text { sistem beasiswa tersebut }\end{array}$ \\
\hline 3 & $\begin{array}{l}\text { Terdapat proses } \\
\text { pengumpulan berkas } \\
\text { kembali ke Bidang } \\
\text { Kesejahteraan } \\
\text { Mahasiswa }\end{array}$ & $\begin{array}{l}\text { Diharapkan terdapat sistem } \\
\text { sehingga data diinputkan } \\
\text { oleh mahasiswa melalui } \\
\text { sistem beasiswa tersebut }\end{array}$ \\
\hline 4 & $\begin{array}{l}\text { Pada SOP yang } \\
\text { digunakan saat ini } \\
\text { terdapat Direktorat } \\
\text { Akademik yang } \\
\text { menerima laporan } \\
\text { penerima beasiswa } \\
\text { eksternal, tetapi proses } \\
\text { bisnis yang berjalan tidak }\end{array}$ & $\begin{array}{l}\text { Untuk SOP perbaikan tidak } \\
\text { di gambarkan Direktorat } \\
\text { Akademik dalam prosedur } \\
\text { layanan beasiswa eksternal }\end{array}$ \\
\hline
\end{tabular}




\begin{tabular}{|l|l|c|}
\hline No & Baseline Architecture & Target Architecture \\
\hline & $\begin{array}{l}\text { melibatkan Direktorat } \\
\text { Akademik lagi }\end{array}$ & \\
\hline
\end{tabular}

\section{B. Phase C: Information System Architecture}

\section{Arsitektur Data}

a) Baseline Architecture

Tabel V menampilkan data yang digunakan dalam sistem Informasi.

TABEL V DATA CATALOG

\begin{tabular}{|c|l|}
\hline Nama Data & \multicolumn{1}{|c|}{ Keterangan } \\
\hline \multirow{5}{*}{ Acc Beasiswa } & Data semua yang mendapatkan beasiswa. \\
& Terdapat komponen data yaitu No \\
& Persetujuan, NRP, Nama Mahasiswa, IPK, P, \\
& SKS Reg, SKS SA, Blk, Kategori Beasiswa, \\
& Pengajuan, Kode Beasiswa, Fakultas, Prodi, \\
& Alamat, Telp, Semester, Tanggal Persetujuan, \\
& Batas IPK, Masa Kerja Orang Tua, Angkatan, \\
& SKS, Besaran SKS, Tagihan SKS, Tagihan \\
& Pengembangan, Potongan Beasiswa \\
\hline
\end{tabular}

\begin{tabular}{|l|l|}
\hline \multicolumn{1}{|c|}{ Nama Data } & \multicolumn{1}{|c|}{ Keterangan } \\
\hline & $\begin{array}{l}\text { Pengembangan, Potongan Beasiswa SKS, } \\
\text { Potongan Beasiswa Blok, dan Total } \\
\text { Potongan. }\end{array}$ \\
\hline $\begin{array}{l}\text { Acc Beasiswa } \\
\text { Mahasiswa Baru }\end{array}$ & $\begin{array}{l}\text { Data semua mahasiswa baru yang } \\
\text { mendapatkan beasiswa. Terdapat komponen } \\
\text { data yaitu No persetujuan, No, No Test, } \\
\text { Nama Mahasiswa, SPW, Pengembangan (\%), } \\
\text { Pengembangan (Rp), SKS Reg, SKS SP, } \\
\text { Blok/Paket, dan Kategori Beasiswa. }\end{array}$ \\
\hline $\begin{array}{l}\text { Acc Megister } \\
\text { Prof Akun }\end{array}$ & $\begin{array}{l}\text { Data semua mahasiswa S2 yang mendapatkan } \\
\text { beasiswa. Terdapat komponen data yaitu No } \\
\text { persetujuan, No, NRP, Nama Mahasiswa, }\end{array}$ \\
& $\begin{array}{l}\text { IPK, Potongan langsung, Kategori Beasiswa, } \\
\text { Pengajuan, Kode Beasiswa, Fakultas, Prodi, }\end{array}$ \\
& Alamat, Telp, Semester, Tgl Persetujuan, \\
Batas IPK, dan Masa Kerja Orang Tua.
\end{tabular}

b) Target Architecture

Target Architecture digambarkan pada gambar 2 dalam bentuk entity relationship diagram sebagai berikut:

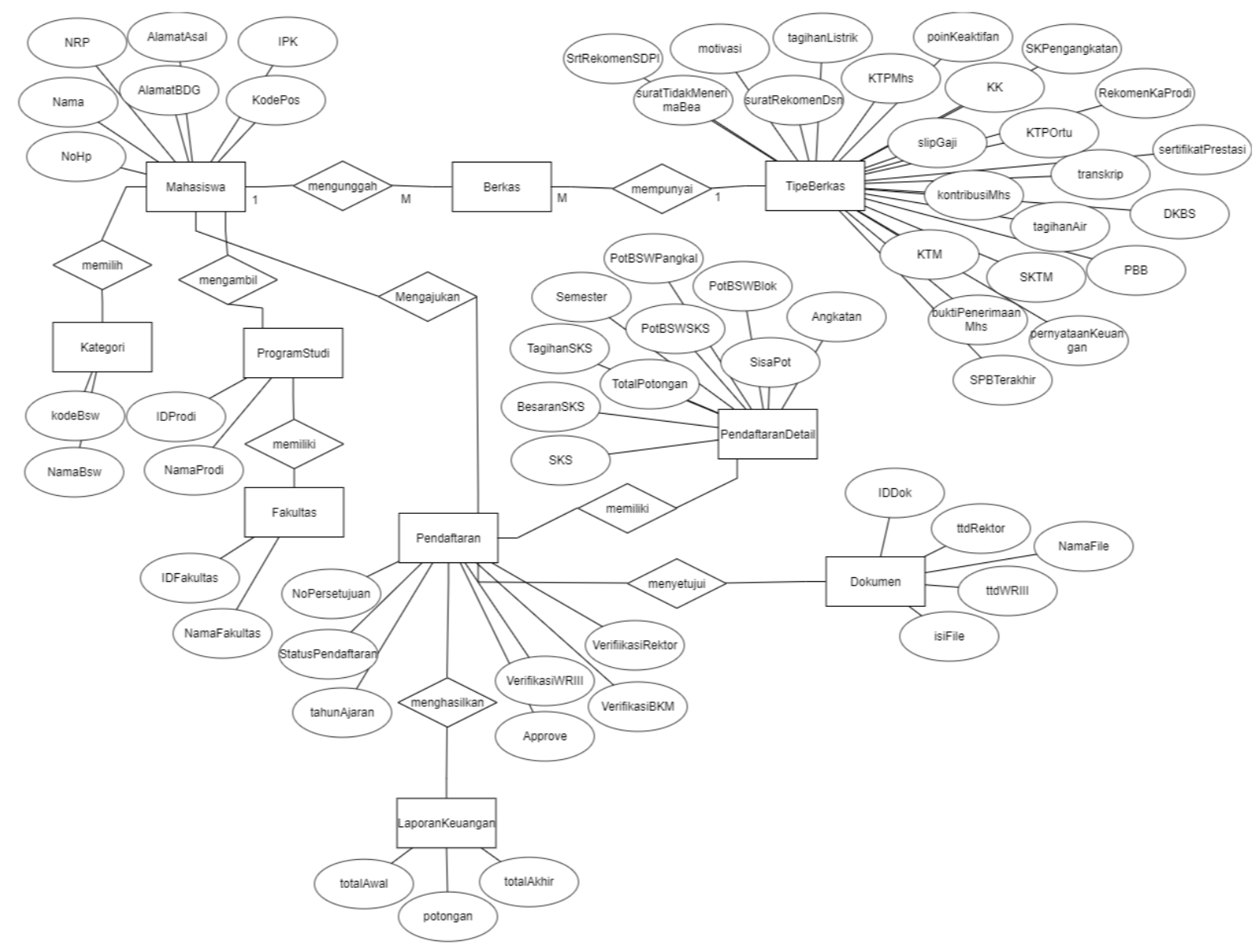

Gambar 2 Entity Realtionship Diagram 


\section{Arsitektur Aplikasi}

a) Baseline Architecture

Prosedur layanan beasiswa yang terbagi atas 4 tahap yaitu tahapan pengajuan, tahapan rekomendasi, tahapan penetapan presentase dan tahapan penerbitan surat penerimaan. Semua tahapan masih dilakukan secara manual.

Pengelolaan beasiswa pada Universitas Kristen Maranatha dikelola oleh Bidang Kesejahteraan Mahasiswa yang berada di bawah pengawasan Direktorat Kemahasiswaan yang melakukan pengelolaan dan perekapan beasiswa menggunakan sistem dalam bentuk file digital (excel) yang memungkinkan kesalahan input data (human error) dan tidak adanya sistem yang terintegrasi yang meminimalisir kesalahan yang mungkin akan terjadi pada pemberian beasiswa.

b) Target Architecture

i. Usecase Diagram

Dalam analisa kebutuhan sistem dibuat dalam bentuk usecase diagram. Pada usecase diagram pada gambar 3 terdapat 9 aktor yaitu Admin, Mahasiswa, Unit Kerja Fakultas, Bidang Kesejahteraan Mahasiswa, Wakil Rektor III, Rektor, Direktorat Keuangan, Direktorat Sumber Daya dan Pengembangan Insani. Setiap aktor memiliki hak akses masing-masing untuk melakukan login. Setiap aktor harus melakukan login terlebih dahulu untuk dapat mengakses sistem pengelolaan beasiswa.

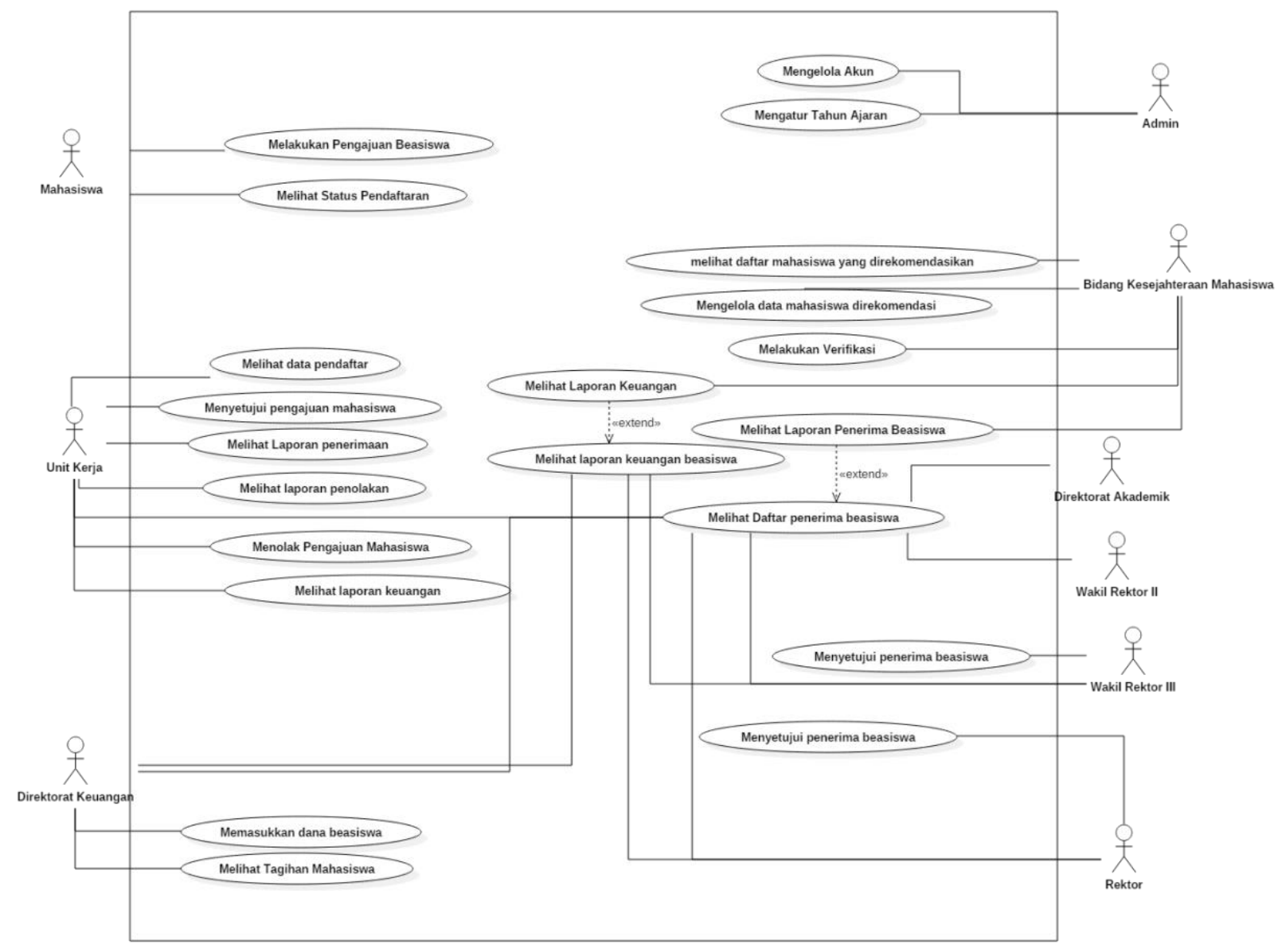

Gambar 3 Usecase Diagram

Gambar 3 menampilkan usecase diagram fungsionalitas sistem yang dirancang.

\section{ii. User Interface}

Gambar 4 merupakan tampilan admin dalam melakukan pengelolaan terhadap hak akses aktor yaitu Unit Kerja, Bidang Kesejahteraan Mahasiswa, Wakil Rektor III, Direktorat Keuangan, dan Direktorat Sumber Daya dan Pengembangan Insani.
Gambar 5 merupakan tampilan awal ketika melakukan login sebagai mahasiswa, halaman awal menampilkan informasi pengumuman beasiswa yang ada dengan deadline pengumpulan untuk setiap jenis beasiswa.

Gambar 6 merupakan tampilan apabila mengklik tombol daftar mahasiswa pada menu data master. Menu tersebut akan menampilkan daftar mahasiswa yang mengajukan beasiswa. Terdapat fungsi filter kategori 
untuk melihat mahasiswa berdasarkan kategori yang dipilih serta terdapat fungsi filter berdasarkan prodi.

Gambar 7 merupakan tampilan apabila mengklik menu laporan penerimaan internal dan memilih menu sesuai fakultas mana agar dapat melihat daftar mahasiswa yang direkomendasikan untuk menerima beasiswa internal
Gambar 8 merupakan tampilan menu daftar penerima beasiswa. Direktorat Sumber Daya dan Pengembangan Insani, Rektor serta Direktorat Keuangan juga diberi akses untuk melihat daftar penerima beasiswa.

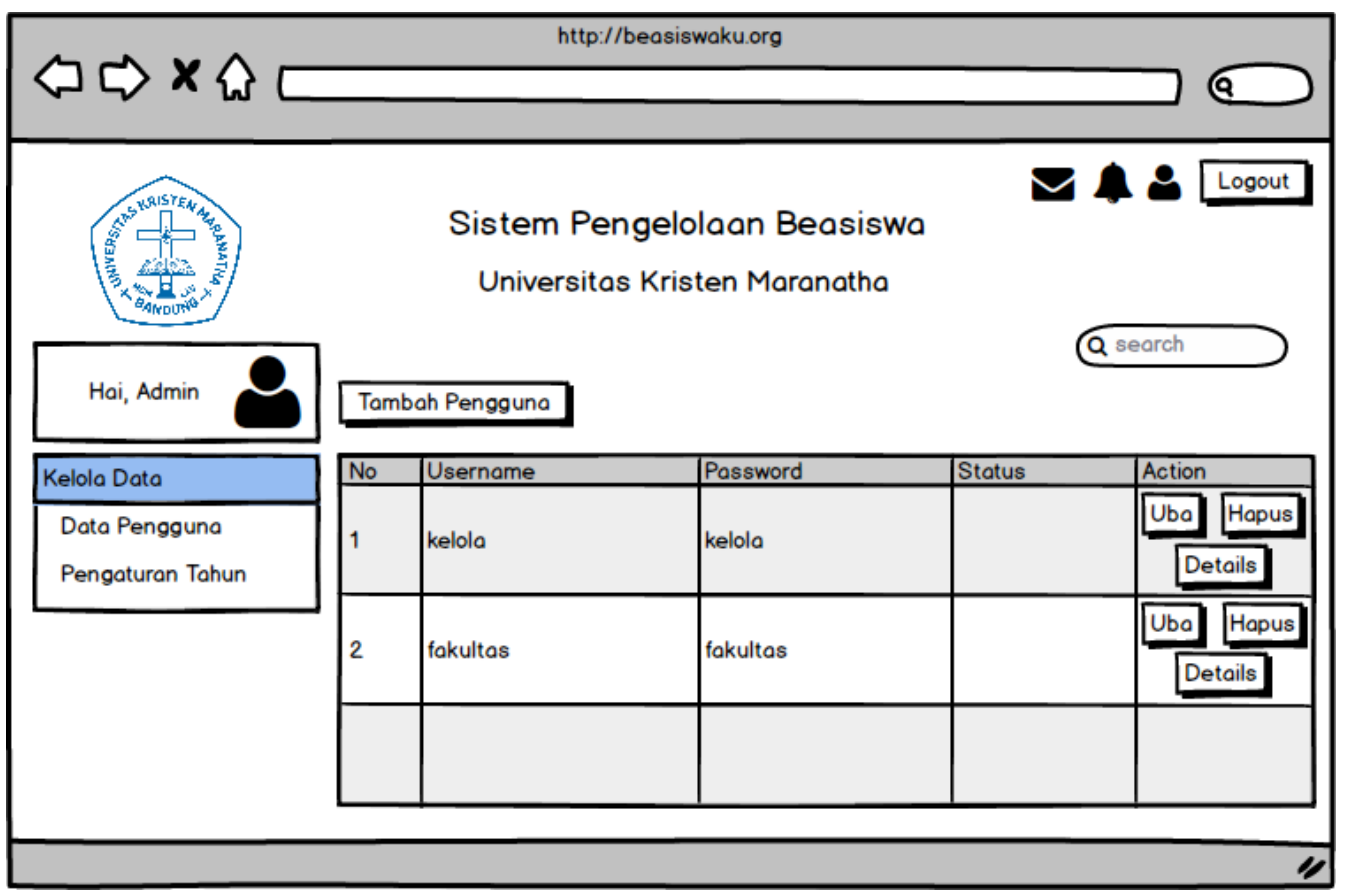

Gambar 4 Tampilan Awal Admin

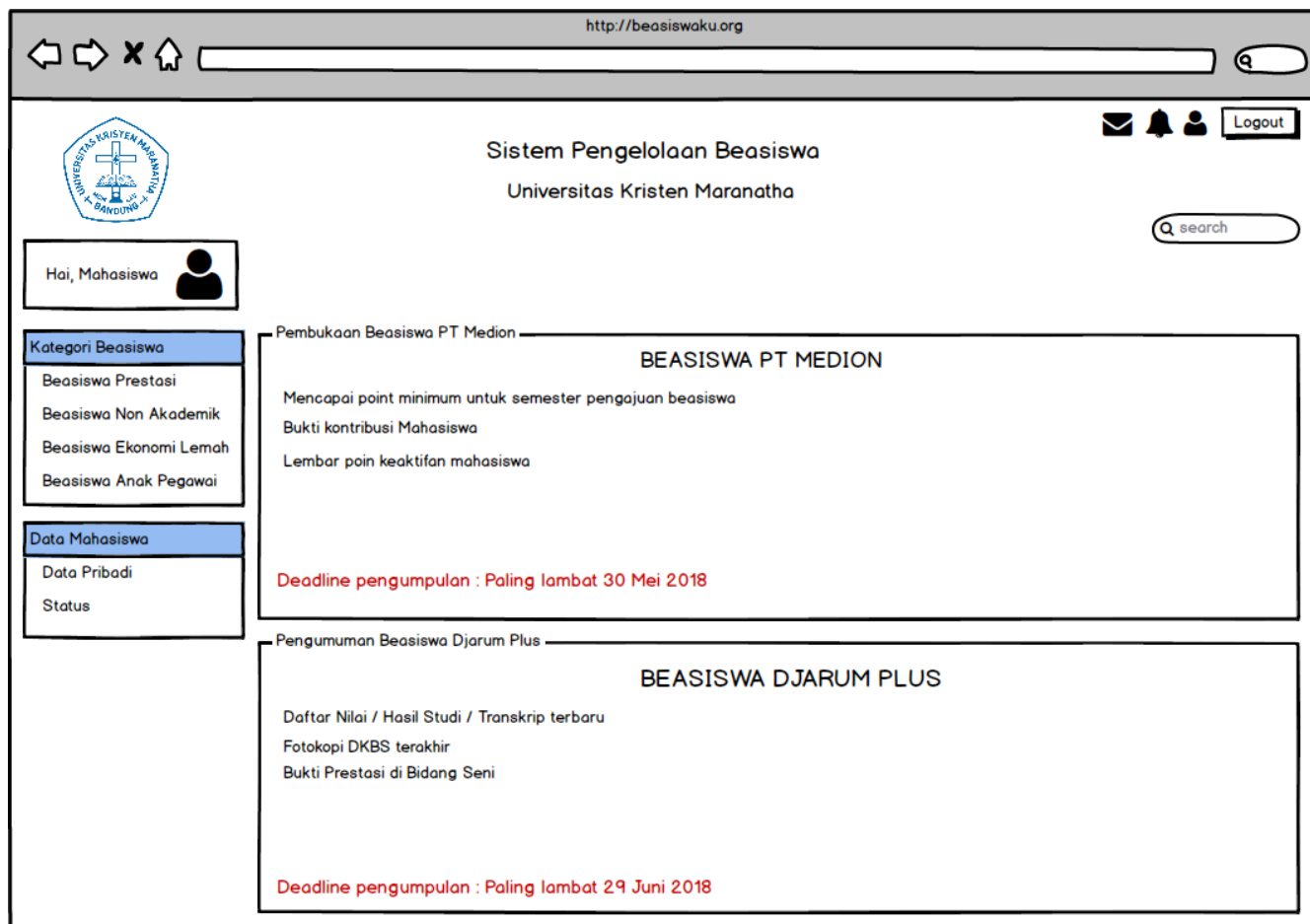

Gambar 5 Tampilan Awal Aktor Mahasiswa 


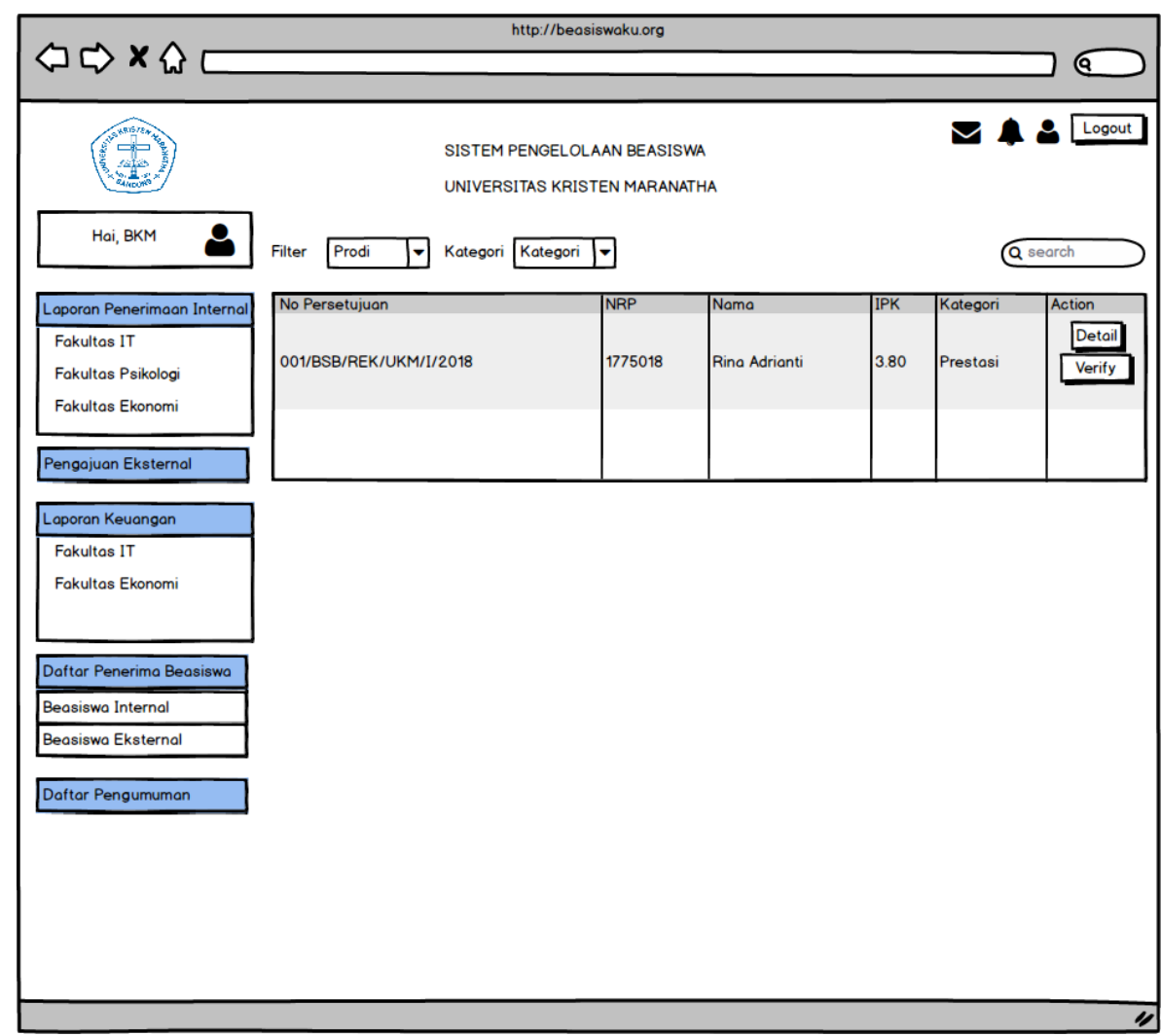

Gambar 6 Tampilan Awal Aktor Unit Kerja Fakultas

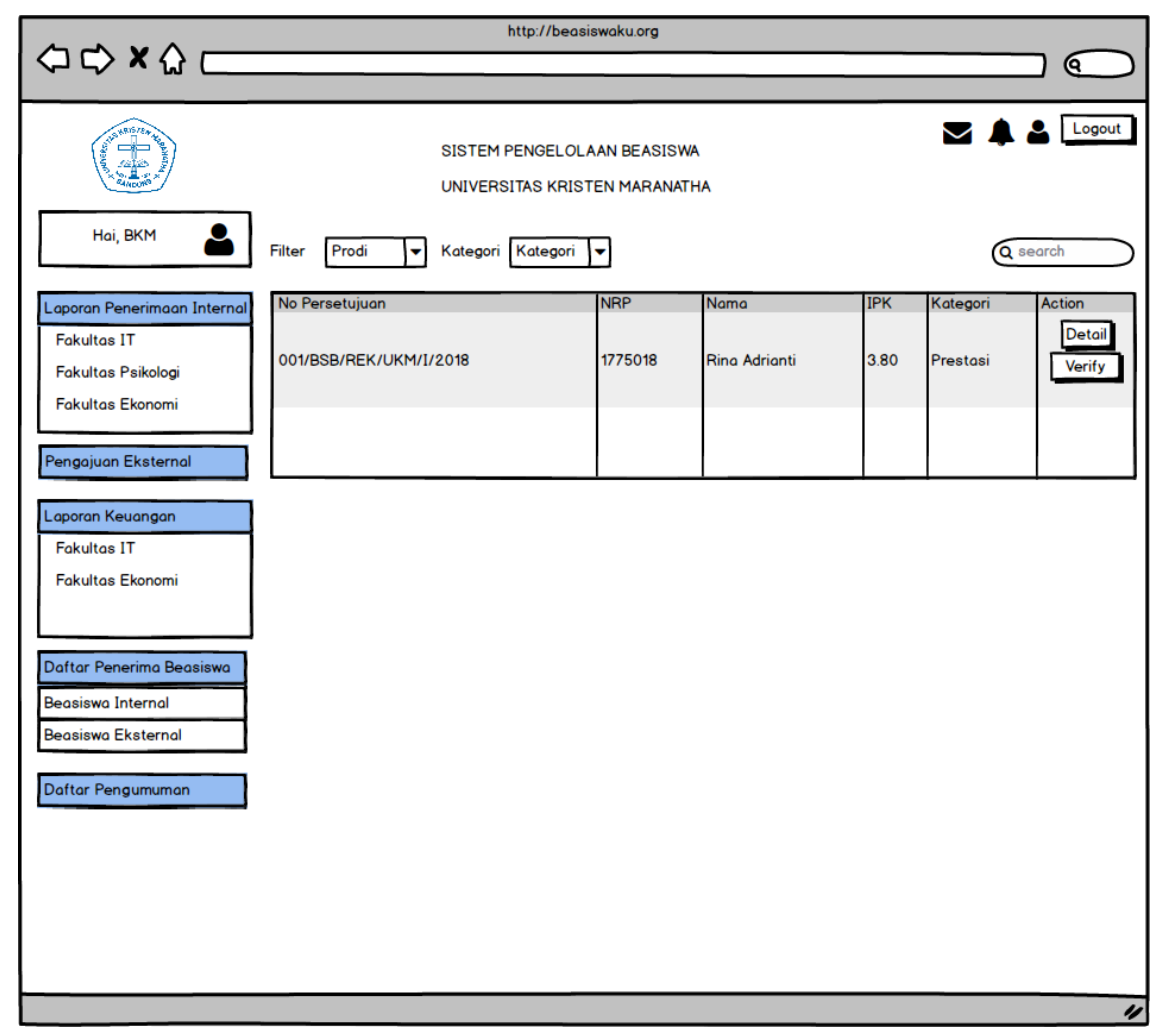

Gambar 7 Tampilan Awal Aktor Bidang Kesejahteraan Mahasiswa 


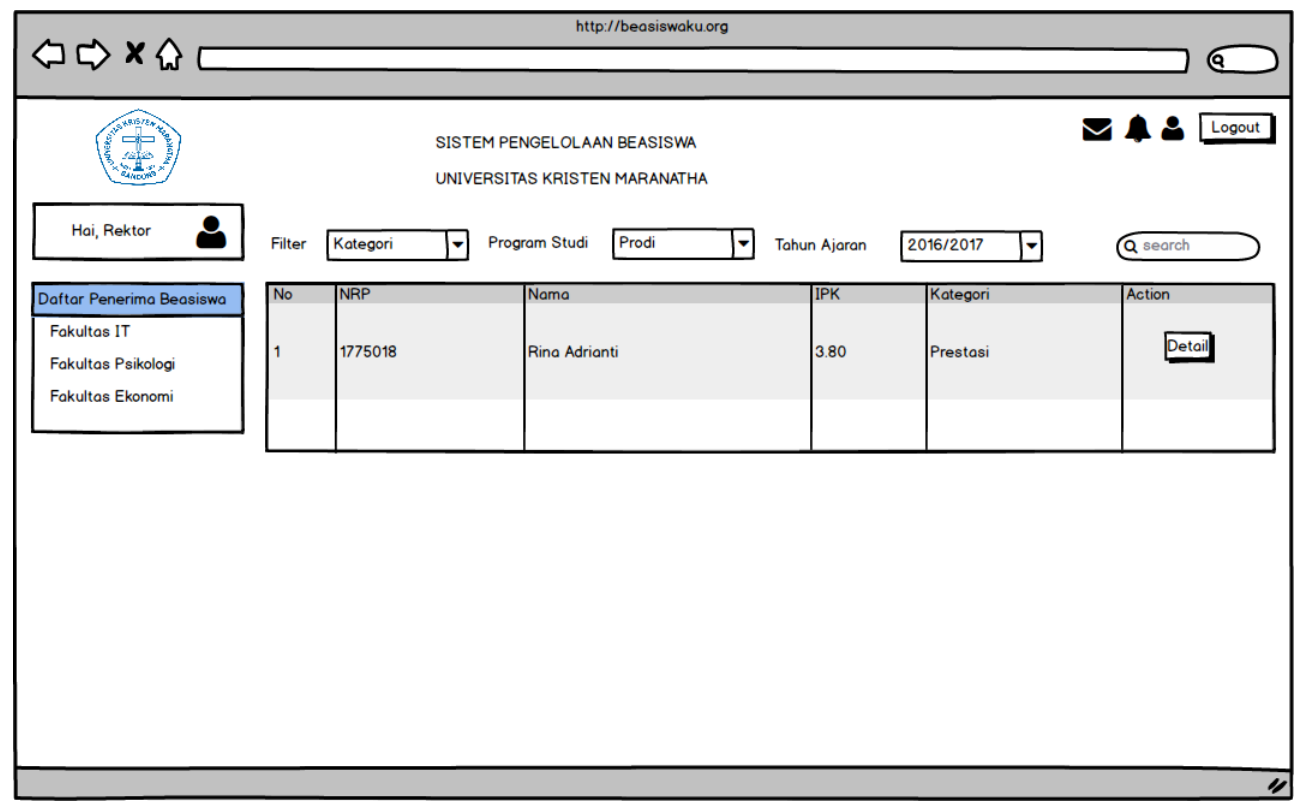

Gambar 8 Tampilan Awal Aktor Rektor, Direktorat Sumber Daya dan Pengembangan Insani, dan Direktorat Keuangan

c) Gap Analysis

Gap analysis antara baseline architecture dengan target architecture ditampilkan pada tabel VI berikut

$$
\text { TABEL VI }
$$

GAP ANALYSIS BASELINE DAN TARGET ARCHITECTURE

\begin{tabular}{|c|c|}
\hline Baseline Architecture & Target Architecture \\
\hline $\begin{array}{l}\text { Baseline application untuk } \\
\text { beasiswa internal: } \\
\text { - Penggunaan Ms. Excel } \\
\text { dalam mengelola layanan } \\
\text { beasiswa } \\
\text { - Belum memiliki sistem } \\
\text { yang menangani tentang } \\
\text { pengelolaan beasiswa } \\
\text { pada Universitas Kristen } \\
\text { Maranatha } \\
\text { - Belum memiliki sistem } \\
\text { yang menangani tentang } \\
\text { pengajuan beasiswa } \\
\text { Belum memiliki sistem } \\
\text { yang terintegrasi untuk } \\
\text { update biaya perkuliahan } \\
\text { Belum memiliki sistem } \\
\text { yang dapat menghitung } \\
\text { budget secara otomatis }\end{array}$ & $\begin{array}{l}\text { Membutuhkan sistem } \\
\text { yang saling terintegrasi } \\
\text { yang mencakup semua } \\
\text { kebutuhan stakeholder } \\
\text { dalam proses } \\
\text { pengelolaan beasiswa } \\
\text { pada Universitas Kristen } \\
\text { Maranatha. }\end{array}$ \\
\hline $\begin{array}{l}\text { Baseline application untuk } \\
\text { beasiswa eksternal: } \\
\text { - Proses pengumuman } \\
\text { pembukaan beasiswa } \\
\text { eksternal dalam bentuk } \\
\text { manual } \\
\text { - Proses pengambilan form } \\
\text { dalam bentuk manual }\end{array}$ & $\begin{array}{l}\text { Membutuhkan sistem } \\
\text { yang bisa menginputkan } \\
\text { pengumuman beasiswa } \\
\text { internal sehingga proses } \\
\text { pendaftaran sampai } \\
\text { proses penerimaan } \\
\text { dilakukan dengan } \\
\text { menggunakan sistem } \\
\text { layanan beasiswa. }\end{array}$ \\
\hline
\end{tabular}

\section{C. $\quad$ Phase D: Technology Architecture}

\section{Baseline Architecture}

\section{a. Spesifikasi Hardware dan Software}

Tabel VII dan tabel VIII menampilkan spesifikasi dari perangkat lunak dan perangkat keras yang diperlukan di dalam sistem Informasi.

TABEL VII

SPESIFIKASI HARDWARE

\begin{tabular}{|l|l|}
\hline \multicolumn{1}{|c|}{ Nama } & \multicolumn{1}{c|}{ Spesifikasi } \\
\hline Sistem Operasi & Microsoft Windows 7 \\
\hline Processor & Intel Core I3 \\
\hline RAM & $4 \mathrm{~Gb}$ \\
\hline Hardisk & $500 \mathrm{~Gb}$ \\
\multicolumn{2}{|c|}{ TABEL VIII } \\
\begin{tabular}{|l|l|}
\hline \multicolumn{2}{|c|}{ SPESIFIKASI SOFTWARE } \\
\hline Nama & Spesifikasi \\
& 2007dan Excel 2007 \\
\hline
\end{tabular}
\end{tabular}

\section{Target Architecture}

Target Architecture terbagi atas 2 yaitu sisi client dan sisi server. Untuk sisi client tetap dapat menggunakan spesifikasi yang dimiliki baseline architecture teknologi. Untuk topologi jaringan fisik komunikasi beserta spesifikasi perangkat kerasnya dapat dilihat pada tabel IX dan gambar 9 . 
TABEL IX

SPESIFIKASI SERVER

\begin{tabular}{|l|l|}
\hline \multicolumn{1}{|c|}{ Nama } & \multicolumn{1}{|c|}{ Spesifikasi } \\
\hline Processor & $\begin{array}{l}\text { Intel Core i7-4790K 4.0Ghz Up To } \\
\text { 4.4Ghz - Cache 8MB }\end{array}$ \\
\hline Motherboard & Asrock Fatal1ty Z97 Anniversary \\
\hline Hardisk & WDC 1TB SATA3 64MB - Caviar \\
& $\begin{array}{l}\text { Blue } \mathrm{x} \text { (Lakukan RAID10, untuk } \\
\text { keamanan data dan performa kecepatan }\end{array}$ \\
\hline$R A M$ & $\begin{array}{l}\text { Team Xtreem Dark DDR3 PC19200 } \\
\text { 2400Mhz Dual Channel 16GB } \\
\text { (2x8GB) 11-13-13-35 }\end{array}$ \\
\hline$P S U$ & Zumax Power ZU500 - 500W - 80 \\
& Bronze Certified - Japanese Version \\
\hline
\end{tabular}

Berdasarkan baseline architecture technology yang telah dijabarkan dengan melihat target architecture application maka tabel $\mathrm{X}$ berikut adalah table gap analysis yang dihasilkan:

TABEL $X$

GAP ANALYSIS

\begin{tabular}{|l|l|}
\hline \multicolumn{1}{|c|}{ Baseline Architecture } & \multicolumn{1}{|c|}{ Target Architecture } \\
\hline Penggunaan Ms. Excel & Terdapat database untuk \\
sebagai tools yang & menyimpan semua data - data \\
digunakan dalam & pengelolaan beasiswa \\
\cline { 2 - 2 } mengelola beasiwa & Menggunakan storage atau media \\
sangat beresiko keruskan & penyimpanan data dengan jumlah \\
data (corrupt). & slot banyak lakukan RAID10 \\
& untuk keamanan data dan \\
& performa kecepatan \\
\hline
\end{tabular}

\section{Gap Analysis}

Usulan topologi infrastruktur jaringan digambarkan pada gambar 9

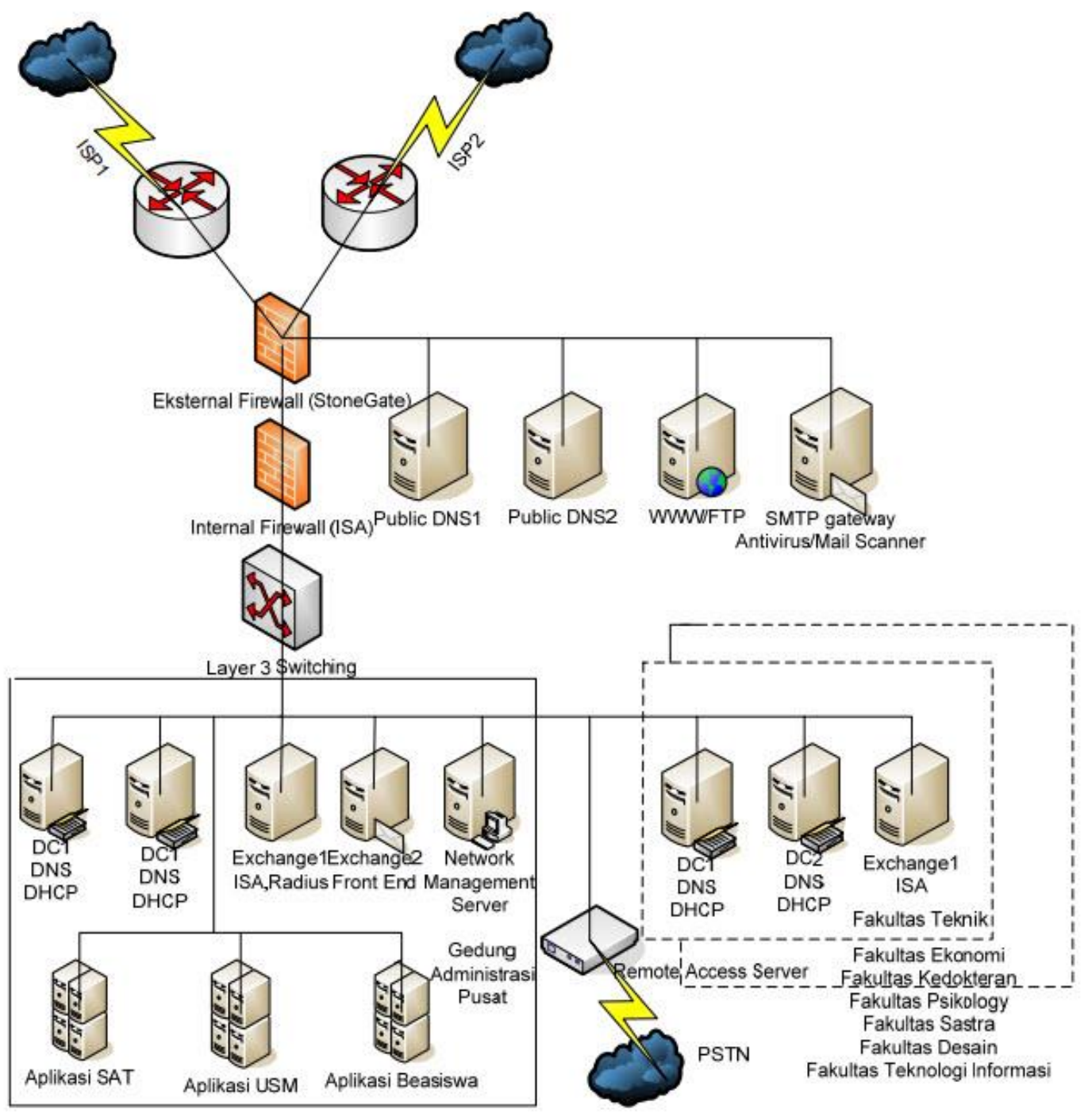

Gambar 9 Topologi Jaringan UKM [10] 


\section{KESIMPULAN}

1. Telah dihasilkan blueprint Arsitektur Enterprise dengan stusi kasus Layanan Beasiswa UKM, yang mendefinisikan setiap komponen perancangan secara lengkap dengan menggunakan framework Togaf 9.1, mulai dari Phase B Businness Architecture, Phase C Information System Architecture, dan Phase D Technology Architecture. Blueprint ini dapat dijadikan pedoman dalam pembangunan sistem pengelolaan beasiswa di UKM.

2. Perancangan arsitektur TOGAF ADM memiliki banyak artefak, tetapi dalam penelitian ini tidak seluruh artefak digunakan sehingga diharapkan bagi penelitian selanjutnya mampu menggambarkan artefak TOGAF ADM secara lengkap.

\section{DAFTAR PUSTAKA}

[1] A. D. Putera, "Kompas.com," 16 Juli 2018. [Online]. Available: https://ekonomi.kompas.com/read/2018/07/16/130732026/bps-maret2018-persentase-kemiskinan-indonesia-terendah-sejak-1999. [Accessed 15 Oktober 2018].

[2] E. Murniasih, Buku Pintar Beasiswa, Jakarta: Gagas Media, 2009.
[3] E. Murniasih, Winning A Scholarship, Jakarta: GagasMedia, 2008.

[4] "Badan, Lembaga dan Direktorat," Universitas Kristen Maranatha, [Online]. Available: https://www.maranatha.edu/profile/badanlembaga-dan-direktorat/. [Accessed 18 January 2018].

[5] "Beasiswa," Universitas Kristen Maranatha, [Online]. Available: https://www.maranatha.edu/scholarship/beasiswa/. [Accessed 15 October 2018].

[6] E. B. Setiawan, "PEMILIHAN EA FRAMEWORK," in Seminar Nasional Aplikasi Teknologi Informasi 2009 (SNATI 2009), Yogyakarta, 2009.

[7] D. Minoli, Enterprise Architecture A to Z: Frameworks, Business ProcessModeling, SDA and Infrastructure Technology, CRC Press, 2008.

[8] S. Bernard, An Introduction to Enterprise Architecture, United States America: Author House, 2005

[9] T. Group, Togaf 9.1 Version Enterprise Edition (12th ed), San Fransisco : The Open Group, 2011.

[10] D. Greehorst, "TOGAF \& Major IT Frameworks,Architecting the Family," ITpreneurs, 2013.

[11] Y. Hutama, A. A. Arry and Y. Romansyah, "Perancangan Enterprise Architecture Menggunakan TOGAF Framework 9.0 dan Content Framework (Studi Kasus BAA Universitas Kristen Maranatha), Electrical Engineering Journal, vol. 5, no. 1, pp. 45-62, 2014. 